\title{
Socio-demographic and obstetric profile of pregnant women in a public hospital*
}

\author{
Perfil sociodemográfico e obstétrico de parturientes de um hospital público
}

Elaine Marcelina Barbosa ${ }^{1}$, Andressa Suelly Saturnino de Oliveira ${ }^{1}$, Dayze Djanira Furtado de Galiza ${ }^{1}$, Valéria Lima de Barros ${ }^{1}$, Valdenici Firmo de Aguiar ${ }^{1}$, Marilia Braga Marques ${ }^{2}$

Objective: to investigate the sociodemographic and obstetric profile of pregnant women in a public hospital. Methods: descriptive, documentary study with information contained in a record book created based on the Certificate of Live Birth of 323 pregnant women. Results: it was observed that $69.3 \%$ of pregnant women were between 20 and 35 years old, $70.0 \%$ had elementary school educaiton, $74.3 \%$ had a partner, $78.6 \%$ were farmers and $8.4 \%$ had remunerated activity. $51.7 \%$ were primiparous, $70.6 \%$ had six or more prenatal visits. In the association of variables, it was noticed that mothers between 15 and 19 years of age showed higher index of primiparity $(78.6 \%$; $\mathrm{p}<0.001)$, the low educational level was related with the increase of children $(71.7 \%$; $\mathrm{p}=0.002$ ) and vaginal delivery (56.9\%; $\mathrm{p}=0.045)$. Conclusion: it was evident a large percentage of primiparity in adolescents, low educational level among mothers with many children and those who underwent vaginal deliveries.

Descriptors: Live Birth; Information Systems; Maternal and Child Health.

Objetivo: investigar o perfil sociodemográfico e obstétrico de parturientes de um hospital público. Métodos: estudo documental descritivo, realizado com informações contidas em um livro de registros elaborado baseado na Declaração de Nascido Vivo de 323 parturientes. Resultados: observou-se que 69,3\% das parturientes tinham entre 20 e 35 anos, 70,0\% ensino fundamental, 74,3\% possuíam companheiro, 78,6\% eram lavradoras e 8,4\% detinham atividade remunerada. 51,7\% eram primíparas, 70,6\% realizaram seis ou mais consultas pré-natal. $\mathrm{Na}$ associação de variáveis, percebeu-se que as mães entre 15 e 19 anos exibiam alto índice de primiparidade (78,6\%; $\mathrm{p}<0,001)$, a baixa escolaridade relacionou-se com o aumento de filhos $(71,7 \%$; $\mathrm{p}=0,002)$ e com o parto vaginal (56,9\%; $\mathrm{p}=0,045)$. Conclusão: evidenciou-se grande percentual de primiparidade em adolescentes, baixa escolaridade em mães com maior número de filhos e nas que realizaram partos vaginais.

Descritores: Nascimento Vivo; Sistemas de Informação; Saúde Materno-Infantil.

\footnotetext{
*Excerpted from the Conclusion Course Work "Perfil das parturientes e nascidos vivos de um hospital público", Universidade Federal do Piauí, 2014.

${ }^{1}$ Universidade Federal do Piauí. Picos, PI, Brazil.

${ }^{2}$ Universidade Federal do Ceará. Fortaleza, CE, Brazil.
}

Corresponding author: Elaine Marcelina Barbosa

Rua Presidente Castelo Branco, 190, Junco, CEP: 64.607-825. Picos, PI, Brazil. E-mail: elainembbio@hotmail.com 


\section{Introduction}

Considering population's growth and women's needs, the Ministry of Health implemented the National Policy of Integral Care to Women's Health, in order to provide improvements to women's health and consolidate advances in the field of sexual and reproductive rights ${ }^{(1)}$.

The National Policy of Integral Care to Women's Health aims to expand, qualify and humanize assistance to women's health. In order to achieve this goal, the Ministry of Health has made use of new strategies. Among these, the Stork Network is mentioned, consisting of a care network that aims to foster the implementation of new care model to women's and children's health, focusing in care during labor, birth, growth and development of children until their twenty-four months of age; ensuring access, welcoming and resolution to labor and birth; and reducing maternal and infant mortality ${ }^{(1-2)}$.

However, to achieve the reduction targets of maternal mortality in Brazil the objectives need to move forward. Thus, the Stork Network includes in prenatal care the early detection of risk situations, as well as quick and intelligent interventions, connection of pregnant women with the maternity, quality delivery care, all this through humanization, ambience, good practices and welcoming with risk rating, factors that provide security, dignity and respect for social, cultural, ethnic, affective and sexual dimensions of labor and birth, and which are considered as determinants of health indicators and potential to reduce the main causes of maternal mortality ${ }^{(2)}$. However, studies have been showing that to put into practice the actions recommended by the Ministry of Health it is necessary to identify the sociodemographic profile of pregnant and postpartum women attended in the Brazilian territory, because this information allows the regionalized situational diagnosis and enable the planning and implementation of assistance health specifically for each territory, providing agility in service and care planning, and consequently the reduc- tion of morbimortality ${ }^{(3-5)}$.

Therefore, maternal issues such as marital status, occupation, age, education, duration of pregnancy, as well as the type of delivery, influence health conditions ${ }^{(3)}$. This way, investigating the characteristics of pregnant women in institutions constitutes a major factor in the direction of the main demands required by the health sector. So the aim of this study was to describe the sociodemographic and obstetric profile of pregnant women treated at a public hospital and to verify the association between the characteristics variables of this population.

\section{Methods}

This is a documental, quantitative and retrospective study. The population of the study consisted of 2011 pregnant women in a public hospital, located in the city of Picos, Brazil, attended during the year of 2012 in the delivery room of the hospital mentioned. The sample (n) was calculated using the formula for finite sample whose confidence level was $95 \%$ $(\mathrm{Z} \alpha=1.96)$; the prevalence rate was $\mathrm{P}=50 \%$ because it was not possible to estimate the percentage with which the phenomenon occurs; the complementary percentage was $Q=50 \%$ and the sample error was 0.05 ( $\mathrm{e}=5 \%$ ), totalizing 323 pregnant women.

Data collection occurred through the book of records used in the hospital delivery room, created based on the Certificate of Live Birth, called by the institution the "Book of Nursery." It is emphasized that for data collection it was used a structured form composed of sociodemographic variables (maternal age, education level, marital status and current occupation) and obstetric (parity, number of prenatal visits, gestational age and type of delivery).

To define the records that constitute the sample from the population, it was used a systematic sampling, in which the elements are chosen according to a repetition factor (fixed interval). In this study, the formula applied corresponded to 2011/323, which showed as a result of rounding $\mathrm{k}=6$. In this case, ev- 
ery six records in the sequence book, it was used one to compose the sample, up to the total amount of the sample.

The data obtained were tabulated in the program Microsoft Excel for Windows ${ }^{\circledR} 2010$ and imported into the software Statistical Package for the Social Sciences, version 20.0. The descriptive analysis was performed by calculating the absolute and relative frequencies. The analytical statistics was performed by the intersection of categorical variables, using the likelihood ratio test (LRT). For statistical significance, it was used $\mathrm{p}<0.05$ as a reference value.

The study respected the formal requirements contained in the national and international regulatory standards for research involving human subjects.

\section{Results}

From the 323 records analyzed, it was found that $69.3 \%$ were between 20 and 35 years old and that $27.9 \%$ were adolescents (age below 20 years old), $48.0 \%$ of mothers had elementary education reached only $22.0 \%$ had middle school education. Regarding marital status, $74.3 \%$ had a partner, and $34.4 \%$ were married and $39.9 \%$ were in a stable relationship with unpaid usual occupation. Among those who did not receive any salary, the highest frequency was farmers or people who did subsistence agriculture (254 women) (Table 1).

As for obstetrical aspects, it is observed in Table 2 that the majority of births (51.7\%) were primiparous women, $70.6 \%$ had at least six prenatal consultations, as recommended by the Ministry of Health and the World Health Organization, 95.1\% achieved gestational age between 37 and 41 weeks, with $4.6 \%$ premature births and cesarean sections being predominant with a quantity of $61.9 \%$.
Table 1 - Socio-demographic characteristics of the parturient of a public hospital

\begin{tabular}{lcc}
\hline Variable & $\mathbf{n ( \% )}$ & IC** 95\% \\
\hline Maternal age (years) & & \\
$\quad<15$ & $6(1.9)$ & $0.4-3.4$ \\
$15-19$ & $84(26.0)$ & $21.0-31.0$ \\
$20-35$ & $224(69.3)$ & $64.3-74.3$ \\
$>35$ & $9(2.8)$ & $0.8-4.8$ \\
Education* & & \\
$\quad$ No education & $4(1.2)$ & $0.0-2.4$ \\
Elementary School & $155(48.0)$ & $42.6-53.4$ \\
$\quad$ Middle School & $71(22.0)$ & $17.5-26.5$ \\
$\quad$ High School & $77(23.8)$ & $19.2-28.4$ \\
College Education & $13(4.0)$ & $2.0-6.0$ \\
Marital status* & & \\
Single/divorced/widowed & $82(25.4)$ & $20.7-30.1$ \\
Married & $111(34.4)$ & $29.2-39.6$ \\
Stable union & $129(39.9)$ & $34.6-45.2$ \\
Usual occupation* & & \\
Paid & & \\
Unpaid & $27(8.4)$ & $5.4-11.4$ \\
*Some instruments did not have this information completed; ** Confidence \\
Index & & \\
& &
\end{tabular}

Table 2 - obstetric data of pregnant women in a public hospital

\begin{tabular}{|c|c|c|}
\hline Variables & n (\%) & $\mathrm{CI}^{* *} \mathbf{9 5 \%}$ \\
\hline \multicolumn{3}{|c|}{ Parity (number of children) } \\
\hline No & $167(51.7)$ & $46.3-57.1$ \\
\hline 1 & $101(31.3)$ & $263-36.3$ \\
\hline $2-4$ & $53(16.4)$ & $12.4-20.4$ \\
\hline$\geq 5$ & $2(0.6)$ & $0.0-1.4$ \\
\hline \multicolumn{3}{|c|}{ Number of prenatal consultations } \\
\hline None & $1(0.3)$ & $0.0-0.9$ \\
\hline $1-5$ & $91(28.2)$ & $23.2-33.2$ \\
\hline$\geq 6$ & $228(70.6)$ & $65.7-75.5$ \\
\hline \multicolumn{3}{|c|}{ Gestational age (weeks) } \\
\hline$<37$ & $15(46)$ & $2.3-6.9$ \\
\hline $37-41$ & $307(95.1)$ & $92.8-97.4$ \\
\hline$\geq 42$ & $1(0.3)$ & $0.0-0.9$ \\
\hline \multicolumn{3}{|c|}{ Type of delivery } \\
\hline Vaginal & $123(38.1)$ & $32.8-43.4$ \\
\hline Cesarean & $200(61.9)$ & $56.6-67.2$ \\
\hline
\end{tabular}


After the descriptive analysis of the results, it was conducted the inferential analysis from the search of association between the socio-demographic and obstetric characteristics, namely: women who were between 15 and 19 years old, mostly primiparous (78.6\%, LRT=49.597; 9 degrees of freedom $\mathrm{p}<0.001$ ); those who had from two to four children had lower education (elementary school) (71.7\%, LRT=30.365; 12 degrees of freedom; $\mathrm{p}=0.002$ ); and this level of education was also associated with vaginal delivery (56.9\%; LRT=9.765; four degrees of freedom; $\mathrm{p}=0.045)$.

\section{Discussion}

The study enabled the design of socio-demographic and obstetric characteristics of pregnant women, who are strongly related to the quality of health care. The need to verify the correlation of these variables is based on the municipalization process of the Unified Health System, triggered after the 1990s, and which has as its basis of support the search for indicators like these, which are local, individualized and specific, in order to highlight barriers and vulnerabilities in the health are, allowing the planning and adoption of systematic measures aimed at correcting the problems present in the current health condition. In spite of the results here consolidated, it stands out as a limitation the scarcity of literature concerning the subject with an aim similar to the one present in this study for Piaui, which prevented a more detailed discussion of the subject of this research, according to the results, as well as the need for more extensive research, involving the population attended in its entirety.

Most pregnant women was in the age group between 20 and 35 years old, and a considerable quantity of teenage mothers was identified. These results were similar to those found in another study in which $61.8 \%$ were in the age group from 21 to 34 years old and $23.9 \%$ were younger than 20 years $^{(6)}$. It is noteworthy that the maternal percentage of adolescents in both studies is above the national average to the year 2014, which was $18.9 \%^{(7)}$, indicating the need for family planning strategies for this age group. A study conducted by the World Health Organization in several countries showed that teenage pregnancy denotes higher risk of complications such as eclampsia, puerperal endometritis, systemic infections, low birth weight, premature birth and serious neonatal conditions, mainly in low and middle income countries ${ }^{(8)}$.

Another important finding was the low level of education between mothers who had elementary and middle school. This result was higher than that observed in other studies, in one of them $52.6 \%$ of the pregnant women were in elementary school and in another only $17.85 \%$ of mothers had the level of study mentioned $^{(3,5)}$.

The low education level may be associated with unfavorable socioeconomic conditions and be considered an obstetric risk factor for the obstruction of the understanding of health education actions, adding damage to the health of mother and child ${ }^{(5)}$.

Regarding marital status a small portion had no companion. This percentage diverged considerably from values observed in other studies, ranging from $71.3 \%$ to $50.3 \%{ }^{(6,9)}$. The prevalence of mothers with support of a partner is considered favorable, since the safe marital status brings improvements to the psychological situation and economic stability ${ }^{(9)}$.

The usual unpaid occupation, mainly farmers or the ones who did subsistence agriculture, represent the vast majority, leaving a small portion of them who had remunerated activity. The quantity of women with paid employment was much lower than that found in another study, which $29.8 \%$ of women performed work with remuneration ${ }^{(10)}$ It is likely that the high percentage of women who reported not having compensation is related to the verified low educational level, because the higher level of education promotes access to employment and better socioeconomic conditions $^{(9)}$.

As for parity, most births occurred in primiparous women, consistent results with the percentage of $46.7 \%$ found in another study ${ }^{(11)}$. These findings 
follow the fertility decline trend indicated by the census of the Brazilian Institute of Geography and Statistics [Instituto Brasileiro de Geografia e Estatística] ${ }^{(12)}$.

The percentage of women who had six or more prenatal visits was $70.6 \%$, exceeding the amount shown in other studies, these ranged from $26.9 \%$ to $58.8 \%{ }^{(3,13)}$.

Several authors agree and highlight that prenatal care is an important factor of protection for both mother and child, since, if performed properly, it gives better results in pregnancy, childbirth and postpartum, reducing complications and maternal and infant morbimortality ${ }^{(14-15)}$.

The quantity of premature births was lower than the $11.9 \%$ of the national average for $2012^{(7)}$ reaching less than half that amount. Regarding the term births, the percentage of values obtained above found in another study, which showed $92.27 \%{ }^{(16)}$ It should be highlighted that the duration of gestation is considered one of the major determinants of intrauterine growth retardation and fetal development problems, constituting a risk factor for neonatal mortality.

The predominant type of delivery was cesarean. The study confirms the increase in cesarean section rates in recent years and the distancing of $15.0 \%$ recommended by the World Health Organization. The national cesarean rates increased from 39.0\% in 2002 to $55.6 \%$ in 2012 . It is important to notice that the results obtained were higher than the percentage of other studies ${ }^{(7)}$.

The high cesarean rates occur in many cases, due to the fact that the prenatal attendance is performed by the medical professional instead of other professionals ${ }^{(17)}$, such as the nurse who has the capacity and legal support for such activity and importance in prenatal care concerning health education.

Primiparity in women between 15 and 19 years old prevailed, highlighting the high rate of primiparous adolescents, worrying piece of information, since the earlier the pregnancy is the higher the risks of com- plications during pregnancy, childbirth and postpartum. Complications related to teenage pregnancy are enhanced when associated with poor socioeconomic and geographical conditions as well as the fragility of the family structure and the difficulty of access to health care services ${ }^{(12,14)}$.

There was an inversely proportional relationship between parity and education, especially with women who had between two and four children, had lower education (elementary school) (71.7\%; LRT $=30.365, p=0.002$ ). Schooling is a key variable for understanding the differences in reproductive health behavior. This is justified because the low educational level is generally linked to low socio-economic status and lack of access to information ${ }^{(12,18)}$.

Adding to the above, it was observed that women with low education had the highest percentage of vaginal deliveries, showing the influence of educational level in choosing the type of delivery, highlighting the biggest probability to occur cesarean delivery. It is also highlighted that on the contrary of pregnant women with access to private services, those who perform prenatal care in public service often do not have the chance to choose the professional who will assist them and probably will not have bargaining power on the type of delivery of their choice ${ }^{(19)}$.

\section{Conclusion}

It was found, therefore, that the majority of mothers were between 20 and 35 years old had education corresponding to elementary education, had a companion, had as occupation subsistence agriculture, were primiparous, had six or more prenatal visits and the type of delivery that prevailed was cesarean. By correlating these variables, it was noticed a large percentage of primiparity in adolescents, low education among mothers with many children and those who underwent vaginal deliveries.

In these circumstances, it was noticed that ac- 
cess to information, knowledge about the reality and the constant monitoring of data, rates and ratios by health professionals, especially nurses, can contribute in the actions developed and in the way of taking care and watching life. Therefore, the variables contained in the Certificate of Live Birth for mothers and children consist of rich data source, depending on how they are understood and interpreted and its application in day-to-day can contribute directly as bank data and be used for planning and foundation of care actions and prevention both in the public health and in the hospital care areas.

\section{Collaborations}

Barbosa EM, Oliveira ASS and Marques MB contributed in the project design, analysis and interpretation of data, drafting of article and final approval for publication. Galiza DDF, Barros VL and Aguiar VF contributed in the analysis and interpretation of data, article writing and final approval of the version to be published.

\section{References}

1. Paz APB, Salvaro GIJ. Comprehensive national policy for women's health: education proposals in spotlight. Rev Eletr Pesquisa Docencia (REID) [Internet]. 2011 [cited 2016 Apr 20]; 121-33. Available from: http://revistaselectronicas.ujaen. es/index.php/reidmonografico/n1/REIDM1art8. pdf

2. Ministério da Saúde (BR). Portaria no 1.459/GM, de 24 de junho de 2011. Institui no âmbito do Sistema Único de Saúde - SUS - a Rede Cegonha. Brasília: Ministério da Saúde; 2011.

3. Secretaria da Saúde do Estado de São Paulo. Coordenação de Epidemiologia e Informação. 0 perfil dos nascimentos na cidade de São Paulo: dez anos do SINASC. São Paulo: Secretaria da Saúde do Estado de São Paulo; 2011.
4. Santos JO, Pacheco TS, Oliveira PS, Pinto VL, Gabrielloni MC, Barbiere M. The obstetrical and newborn profile of postpartum women in maternities in São Paulo. Rev Fundam Care. 2015; 7(1):1936-45.

5. Barbosa CNS, Gonçalves LRR, Silva GRF, Brandão EC, Rego ES, Ferreira MM. Caracterização dos partos segundo aspectos obstétricos e sóciodemográficos das parturientes de Teresina - PI, 2011. Rev Enferm UFPI. 2013; 2(2):40-7.

6. Franciscatto LHG, Pasqua MD, Tolotti GK, Rossetto C, Argent C, Pinheiro JM. Delineamento do perfil epidemiológico de puérperas e recémnascidos. Rev Enferm UFPE on line [Internet]. 2014 citado 2016 abr 20; 8(5):149-56. Disponível em: file:///C:/Users/RENE\%2001/ Downloads/5567-56188-1-PB.pdf

7. Ministério da Saúde (BR). Datasus. Informações de Saúde. Estatísticas vitais. Nascidos Vivos [Internet]. 2017 [citado 2017 fev 16]. Disponível em:http://tabnet.datasus.gov.br/cgi/tabcgi. exe?sinasc/cnv/nvuf.def

8. Ganchimeg T, Ota E, Morisaki N, Laopaiboon M, Lumbiganon P, Zhang J, et al. Pregnancy and childbirth outcomes among adolescent mothers: a World Health Organization multicountry study. BJOG. 2014; 121(1):40-8.

9. Cravo EO, Oliveira JVR. Perfil epidemiológico dos nascidos vivos no município de Aracaju - Sergipe, Brasil. Ideias Inov. 2012; 1(1):9-17.

10. Aratani N, Toledo Neto JL, Silva NMMG, Tashima CM, Castanho SC, Melo S. Preferência pelo tipo de parto entre gestantes primíparas. Rev Odontol. 2014; 14(3):209-24.

11. Silva FFA, Silva RAR, Santos FAPS, Rego AP. Service rendered to parturient at a university hospital. Rev Fundam Care. 2014; 6(1):282-92.

12. Instituto Brasileiro de Geografia e Estatística (BR). Dados populacionais 2010 [Internet]. 2010 [citado 2016 fev 18]. Disponível em: http://www. ibge.gov.br

13. Maciel SSSV, Maciel WV, Oliveira AGL, Sobral LV, Sobral HV, Carvalho ES, et al. Epidemiologia da gravidez na adolescência no município de Caruaru, PE. Rev AMRIGS. 2012; 56(1):46-50. 
14. Santana AM, Almeida SMC, Prado LOM. Urgências/ emergências obstétricas $\mathrm{x}$ assistência ao pré-natal. Cad Grad Ciênc Biolol Saúde. 2010; 11(11):51.

15. Asundep NN, Jolly PE, Carson A, Turpin CA, Zhang K, Tameru B. Antenatal care attendance, a surrogate for pregnancy outcome? The case of Kumasi, Ghana. Matern Child Health J. 2014; 18(5):1085-94.

16. Rodrigues KSF, Zagonel IPS. Perfil epidemiológico de nascimentos em foz do Iguaçu/PR: indicador para planejamento do cuidado do enfermeiro. Esc Anna Nery. 2010; 14(3):534-42.
17. Copelli FHS, Rocha, L, Zampieri, MFM, Gregório, VRP, Custódio, ZAO. Determinants of women's preference for cesarean section. Texto Contexto Enferm. 2014; 24(2):336-43.

18. Sanches NC, Mamede FV, Vivancos RBZ. The profile of women who have experienced cesarean section and obstetric care at a public maternity hospital in Ribeirao Preto. Texto Contexto Enferm. 2012; 21(2):418-26.

19. Patah LEM, Malik AM. Modelos de assistência ao parto e taxa de cesárea em diferentes países. Rev Saúde Pública. 2011; 45(1):185-94. 